\title{
Interrelation Third Party Logistic Risk Impact to The Performance in PT XYZ
}

\author{
Widya Oktavia Rahmawati ${ }^{1}$, Nofrisel ${ }^{2}$ \\ \{widyaor13@gmail.com¹,nofrisel@yahoo.com² \} \\ Magister of Management, Faculty of Economy and Business, Universitas Indonesia \\ Jakarta, Indonesia ${ }^{1,2}$
}

\begin{abstract}
Risk or disruption can occur when a company works on its operations and can affect the performance into customer. In previous studies, there have been many studies that study the various conditions faced by companies both internally, externally and about their relationships with consumers which can have an impact, both positively and negatively on the performance of 3PL companies. Risks or disruptions can occur when they carry out their operational activities, either risk or disruption in terms of providing orientation to their customers, the quality of the relationship between 3PL and its customers or cargo management. This study is a descriptive study which study the relationship between consumer orientation, relationship quality and cargo management based on the perception of PT. 123 as the consumer of the 3PL PT. XYZ and how the relationship between the variables is. Hypothesis testing uses path analysis where the results of testing the hypothesis found that there is an influence between relationship quality and cargo management on the performance of PT $\mathrm{XYZ}$ but for consumer orientation variables does not have an influence on the performance of PT XYZ.
\end{abstract}

Keywords: Disruption, Logistics Risk,s, Interrelation, Operational Performance, Path Analysi

\section{INTRODUCTION}

PT XYZ is a multinational global market leader in the logistics industry. As a 3PL (Third Party Logistics) company with highly skilled in logistics, PT XYZ has a large number of customers who use their services to provide added value to their company's logistics operations. PT 123 as a company which uses logistics services as a customer who acts as the highest income producer in PT XYZ, of course, has a reasons for using this 3PL logistics service provider. PT 123 surrenders its logistical operations to more expert parties so PT 123 can focus more on the real business of the company and also the company does not need to worry when there is a surge in demand or declining logistics services later since using services from PT XYZ as 3PL Company, operational activities in logistics become more flexible. Moreover PT XYZ must be able to maintain the partnership relationship which has been implemented with PT 123 so far. With PT 123 as the highest corporate revenue holder, it shows how many logistics activities are entrusted to PT XYZ compared to other PT XYZ customers. This is a challenge in itself how 
PT XYZ can establish a partnership relationship so as not to disappoint PT 123 and ensure that the logistics activities of PT 123's company remain entrusted to PT XYZ.

Delivery status report shows within a period of 6 months starting from July 2018 to December 2018, 44.18\% shipments are not on time received by the recipients at the destination address. This amount almost indicates that half of the total shipments can be collected by researchers from PT XYZ experience delays in delivery based on request arrival date. However, this delay in delivery does not automatically occur. Several reasons make this delivery happen.

Table 1. Delivery delay factor

\begin{tabular}{lr}
\hline \multicolumn{1}{c}{ Delay delivery factor } & $\%$ \\
\hline Wait confirmation for delivery from & \\
customer & $84.07 \%$ \\
Receiver issue & $5.22 \%$ \\
Permit issue & $3.38 \%$ \\
Site readiness & $2.80 \%$ \\
Community issue & $1.41 \%$ \\
Flight schedule issue & $0.81 \%$ \\
Access limit time & $0.68 \%$ \\
Vessel schedule & $0.62 \%$ \\
\hline
\end{tabular}

*Source: Internal Data (2018)

From internal data source shows eight factors make the goods delivery not on time arrive to the destination based on the request arrival date requested by PT 123. Factors which cause delays in delivery are from the internal and external environment of the company. From these data, founded the biggest contributing factor for delay delivery was in determining the delivery time because the PT XYZ could send orders to the destination when there was second confirmation from PT. 123 to do goods delivery. This is done to anticipate other negative possibilities that might occur if the PT XYZ makes deliveries after order finish prepared in warehouse.

Referencel states it is very useful to be able to understand very well the role of the 3PL which they play in terms of their relationships with consumers to identify, and then reduce, eliminate or agree to all risks that can affect the entire supply chain process (p.178). So this study intends to study the possibility of risk factors in carrying out operational activities that can be faced by the company PT XYZ and how much these risks have impact to other risks because this is closely related to the performance that can be produced by PT XYZ to PT 123, based on opinions or perceptions of 123 parties as users of logistics services PT XYZ. Since the relationship that occurs between PT XYZ and PT 123 is a two-way relationship where each of them can provide input to other parties in order to progress together to improve the performance of each business. The scope of the risk to be analyzed comes from factors related to all kinds of PT XYZ operational activities to PT 123 based on the perceptions or opinions of PT 123.

Operations Strategy Matrix describes two perspectives from market demand and operational resources which are formed in a matrix that describes operational strategies as an intersection of a company's performance goals with its decision area. This emphasizes the intersection between what is needed from operational functions (priority given is a matter relative to each performance goal and how this operational activity tries to get it through a decision has been made (and capabilities have been developed) in each area decisions as in ${ }^{2}$. 
There are five general corporate performance objectives contained in this matrix, namely: Quality, Speed, Dependability, Flexibility, and Cost. A company must have a clear strategy to carry out its operational activities. This is intended to achieve the company's performance goals. When a company has advantages in each of its performance targets, the company can have advantages both in the internal and external side of the company.

In many supply chain functions, the most significant decision is whether to outsource the supply chain function or the company will implement it themselves as mention in3. Companies use outsourcing services to assist their operational activities, will determine which functions will be outsourced. This will depend on company policies such as for a process turns out to be more expensive if outsourced according to the company's perspective, so the company maybe would prefer to be carried out by themselves. Or relating to the company's strategic functions will also be done by the company itself.

Logistics as part of a company's supply chain is very important in terms of material movement from suppliers to buyers, movement of material work in process in a company, movement of finished goods to customers, return or recycling of goods and also in terms of product storage while traveling a chain supply. An effective logistic system is needed in trade to live in various industrialized societies. Furthermore, reference 4 states because the logistics function is to create a time utility and place utility, this logistics element becomes a very important thing in terms of delivering goods to customers routinely to each supply chain customer in a timely manner, and to the correct location and to the desired level of quality and reasonable costs. When errors occur in shipping during the supply chain, companies must have more safety stocks which have an impact on service levels to consumers and costs. To overcome the time wasted, overnight delivery can also be done but it has an impact on the swelling of the shipping bill. In the global supply chain, the logistics function is even more critical. Providing adequate transportation, and storage, obtaining products through customs processes, sending to foreign territories in a timely manner, and calculating prices can have an impact on supply chain capabilities to service foreign markets competitively. In many conditions, companies are forced to use third party logistic services (3PL) to effectively move to unfamiliar locations.

Uncertainty in a global environment where most supply chain operations are carried out requires a strategic plan to evaluate the relative risk of operational activities and the company's supply chain strategy. Risk in the supply chain field is the possibility of a disruption can affect the ability of a company to continue the supply of goods and services as stated in 5 . The risks in the logistics sector have been considered to be a very important category faced in the company such as the risks associated with transportation, storage and warehousing 6. Lews, 2003, Cheong and Song, 2013 as reference in 7mention uncertainty in demand and supply in logistics systems can lead to very high operational risks. Reference 8 states there are negative effects generated in a disruption of a supply chain on financial shareholders (eg Hendricks and Singhal, 2005; Kumar et al., 2015) and also business performance of the company (eg Dabhilkar et al., 2016 ; Ritchie and Brindley, 2007). Disturbances or risks in carrying out logistical operational activities can unwittingly occur either directly or directly and have an impact which takes place directly or indirectly to a company. Good into the 3PL itself which affects the company's image in the eyes of the company's users of logistics services and for the users of logistics services in the eyes of consumers.

In a logistics system, interference can be carried by many factors which can occur naturally In business, it has uncertainty in supply, demand, market prices and costs, normal operational activities (even in the list of disturbances) and this is referred to as operational risk 7. Logistic activities which use land, sea and air transportation lines are inevitable which there unpredictable risks that can haunt them are. Examples are the presence of landslides, floods, 
storms or large winds which can hinder the delivery of goods to the destination. However, in addition to disasters, market conditions can also be a nuisance or risk faced. The uncertainty of market prices and costs for logistics activities can also be a barrier for a 3PL to be able to carry out logistics activities.

Reference 6 states the portfolio of services provided by 3PLs has an impact of the performance of the clients using 3PL services (Rajesh et al,..2011). But, there has been reports of less than successful partnerships with 3PL due to expectation mismatch, poor contracting, etc (Ackerman,1996; Greco,1997). Power et al (2007) report that 3PLs provide opportunities for customer to improve multiple performance elements simultaneously such as cost and flexibility and thus help to overcome tradeoffs between those measures. But, outsourcing of logistic activities also has its own challenge. Lack of responsiveness to customer needs is cited as a problem of outsourcing of logistics functions (van Damme and Amstel, 1996). Disruption to inbound flows, inadequate provider expertise, inadequate employee quality, and inability of 3PL providers to deal with special products need and emergency circumstances, incompatibility of informations system between outsourcing user and 3PL, the failure of 3PL to meet user outsourcing`s future growth needs and lack of security are some risks associated with using services provided by 3PL (Ellram Cooper,1990; van Laarhoven et al.,2000; Svensson,2001; Selviaridis and Spring,2007; Ansari and Modarres,2010; Tsai et al.,2012). At the same time 3PLs themselves face risks from their own operations, due to financial constraints as well as from outsourcings user who transfer its risk to 3PLs"(p. 177-176)

\section{DETAIL EXPERIMENTAL}

This research used 3 variables independen and 1 variable dependen which shown as picture below.

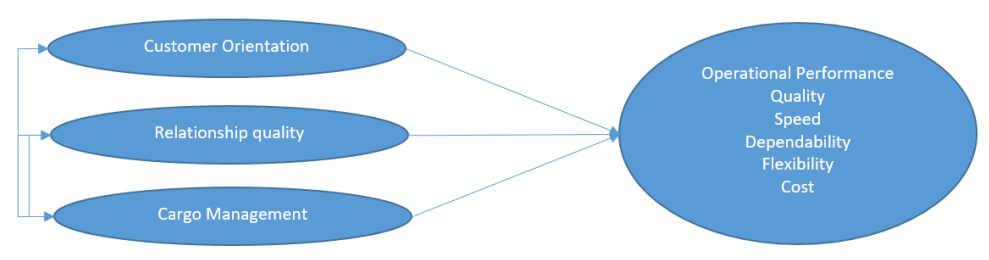

Fig.1 Research Model

With convenience sampling, questionnaire shared to 101 employee in PT. 123 for gained their perception about PT. XYZ regarding variable which will be analysis later. Path analysis used for processing data to prove some hypothesis as below:

H0: Variable customer orientation, relationship quality and management cargo do not affect the performance of PT. XYZ either in simultaneously or partially

H1: Variable customer orientation, relationship quality and management cargo affect the performance of PT. XYZ either in simultaneously or partially 


\section{EXPERIMENTAL RESULT}

For prove relationship simultaneously between independent variable customer orientation, relationship quality \& cargo management to performance in PT. XYZ, we use F test by IBM SPSS which the result shown as below

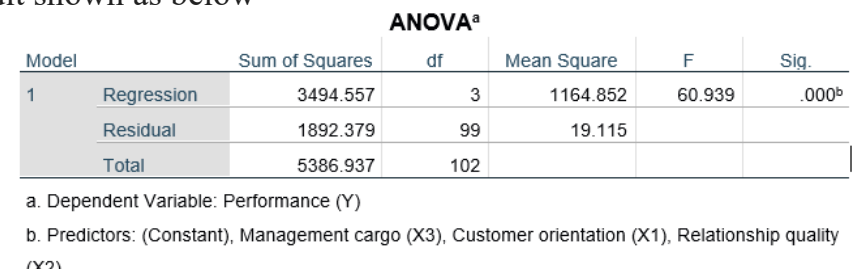

Fig.2 F-Test Result

Based on fig. 1 above shown F test result is 60.939 with sig is 0.000 . Based on decision criteria need $F$ test $>F$ table $(2,70)$ and sig test $<0.05$. Based on this criteria found the result $F$ test passes with result $\mathrm{H} 0$ rejected and $\mathrm{H} 1$ accepted.

For prove partial relationship between independent variable and dependent variable in PT XYZ, we use $t$ test by IBM SPSS which the result shown as below:

$$
\text { Coefficients }^{\mathrm{a}}
$$

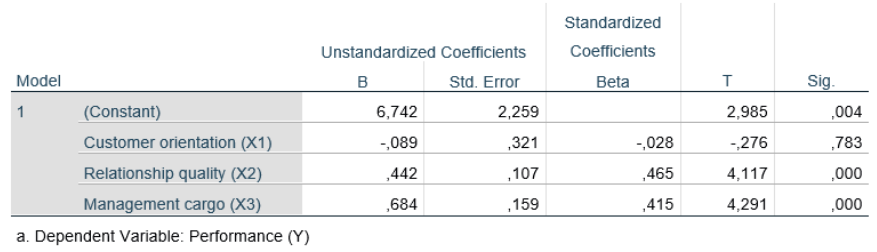

Fig.3 t-test result

Based on fig. 2 above shown $t$ test result for each independent variable relationship to the performance. With the decision criteria $t$ test $>t$ table (1.984) $\mathrm{H} 0$ will be rejected and $\mathrm{H} 1$ accepted and if sig test $<0.05$ shown significant impact, so we have some result as below:

a. Variable customer orientation have $t$ test -0.276 and sig test 0.783 . The result is $\mathrm{H} 0$ accepted and have no significant effect from customer orientation variable to performance variable in PT XYZ.

b. Variable relationship quality have t test 4.117 and sig test 0.000 . The result is $\mathrm{H} 0$ rejected and have significant effect from relationship quality to performance variable in PT XYZ.

c. Variable cargo management have t test 4.291 and sig test 0.000 . The result is $\mathrm{H} 0$ rejected and have significant effect from customer orientation variable to performance variable in PT XYZ.

Since customer orientation variable got $\mathrm{H} 0$ accepted which means there is no relationship between customer orientation to the performance, so this variable will be takeout from research and we use trimming method for re-calculate the result from relationship quality \& cargo management variable. 


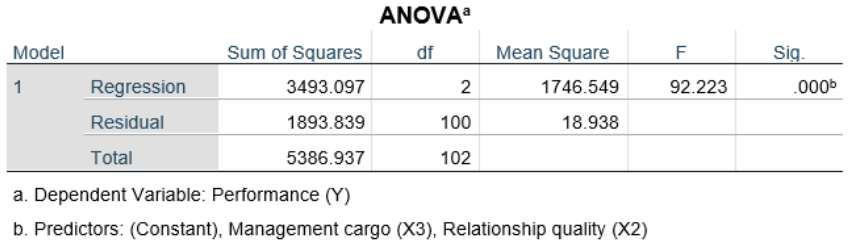

Fig.4 F test result after trimming

Based on fig. 4 above and with criteria which already mention before, got the result $\mathrm{H} 0$ rejected and $\mathrm{H} 1$ accepted. There is a significant relationship between variable relationship quality \& cargo management to the performance PT.XYZ With determination coefficients $64.8 \%$.

Coefficients $^{\mathrm{a}}$

\begin{tabular}{|c|c|c|c|c|c|c|}
\hline \multirow{2}{*}{\multicolumn{2}{|c|}{ Model }} & \multicolumn{2}{|c|}{ Unstandardized Coefficients } & \multirow{2}{*}{$\begin{array}{l}\text { Standardized } \\
\text { Coefficients } \\
\text { Beta }\end{array}$} & \multirow[b]{2}{*}{$\mathrm{t}$} & \multirow[b]{2}{*}{ Sig. } \\
\hline & & B & Std. Error & & & \\
\hline \multirow[t]{3}{*}{1} & (Constant) & 6.550 & 2.140 & & 3.061 & .003 \\
\hline & Relationship quality (X2) & .425 & .089 & .447 & 4.801 & .000 \\
\hline & Management cargo (X3) & .673 & .153 & .409 & 4.387 & .000 \\
\hline
\end{tabular}

a. Dependent Variable: Performance $(Y)$

Fig.5 t-test after trimming

Based on fig. 5 above and with criteria which already mention before, for partial relationship between independent variable and dependent variable, got result as below:

a. Variable relationship quality have $t$ test 4.761 and sig test 0.000 . The result is H0 rejected and hasve significant effect from relationship quality to performance variable in PT XYZ.

b. Variable cargo management have t test 4.387 and sig test 0.000 . The result is $\mathrm{H} 0$ rejected and have significant effect from cargo management to performance variable in PT XYZ.

\begin{tabular}{llr|r} 
& \multicolumn{1}{c}{ Correlations } & $\begin{array}{c}\text { Relationship } \\
\text { quality }(X 2)\end{array}$ & \multicolumn{1}{c}{$\begin{array}{c}\text { Management } \\
\text { cargo }(X 3)\end{array}$} \\
\hline Relationship quality (X2) & Pearson Correlation & 1 & $.771^{-*}$ \\
\cline { 2 - 4 } & Sig. (2-tailed) & 103 & .000 \\
\cline { 2 - 4 } & $\mathrm{N}$ & $.771^{-}$ & 103 \\
\hline \multirow{2}{*}{ Management cargo (X3) } & Pearson Correlation & .000 & 1 \\
\cline { 2 - 4 } & Sig. (2-tailed) & 103 & 103 \\
\cline { 2 - 4 } & $\mathrm{N}$ & &
\end{tabular}

Fig.6 correlation test result

Based on fig. 6 above shown correlation between variable relationship quality and cargo management for 0.771 which means there is a strong relationship between these 2 variable and have a positive coefficient. When 1 variable increase then other variable will do the same.

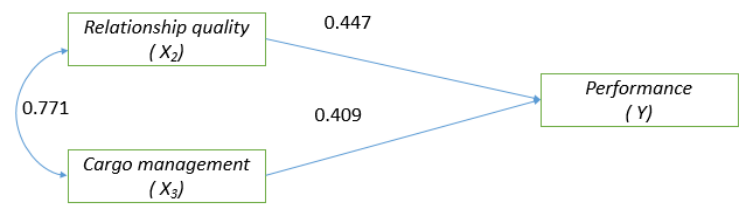


Based on fig 3.5 above shown the relationship accumulative from each variable which have residual factor as 0.593 .so the structural equation is $=0.447 \mathrm{X} 2+0.409 \mathrm{X} 3+0.593 \varepsilon$

\section{CONCLUSION}

Based on the research have some conclusion as below:

1. There are a simultaneously relationship between relationship quality and cargo management

2. There is no significant relationship between customer orientation and performance in PT. $\mathrm{XYZ}$

3. There is a significant relationship between relationship quality and performance in PT XYZ

4. There is a significant relationship between cargo management and performance in PT XYZ

5. Relationship quality variable have a strong relationship with cargo management variable.

\section{REFERENCE}

1. Langley, C. J. Third-party logistics study: the state of logistics outsourcing. Atlanta, GA Capgemini Consult. (2014).

2. Slack, Nigel and Lewis, M. Operations Strategy 4th edition. (Prentice Hall:Harlow, 2015).

3. Chopra, Sunil, \& Meindl, P. Supply Chain Management Strategy, Planning and Operation, fifth global edition. (Pearson Education Limited, 2013).

4. Wisner, Joel D, Tan, Keah-Choon \& Leong, G. K. Supply Chain Management A Balanced Approach. (Nelson Education Ltd, 2012).

5. Jacobs, F. Robert and Chasse, R. B. Operations And Supply Chain management 14th Global Edition. (McGraw Hill, 2014).

6. Govindan, K. \& Chaudhuri, A. Interrelationships of risks faced by third party logistics service providers: A DEMATEL based approach. Transp. Res. Part E Logist. Transp. Rev. 90, 177-195 (2016).

7. Choi, T.-M., Chiu, C.-H. \& Chan, H.-K. Risk management of logistics systems. (2016).

8. Durach, C. F. \& Machuca, J. A. D. International Journal of Operations \&amp; Production Management A matter of perspective-the role of interpersonal relationships in supply chain risk management Article information. Int. J. Oper. Prod. Manag. 38, 205-230 (2018). 